\title{
Haalbaarheidsstudie Regionale Ad-colleges (RAC's) Oost-Brabant en Zuidwest
}

Citation for published version (APA):

Sijbers, E., \& Cörvers, F. (2018). Haalbaarheidsstudie Regionale Ad-colleges (RAC's) Oost-Brabant en Zuidwest. ROA. ROA Technical Reports No. 001 https://doi.org/10.26481/umarot.2018001

Document status and date:

Published: 01/01/2018

DOI:

10.26481/umarot.2018001

Document Version:

Publisher's PDF, also known as Version of record

\section{Please check the document version of this publication:}

- A submitted manuscript is the version of the article upon submission and before peer-review. There can be important differences between the submitted version and the official published version of record.

People interested in the research are advised to contact the author for the final version of the publication, or visit the DOI to the publisher's website.

- The final author version and the galley proof are versions of the publication after peer review.

- The final published version features the final layout of the paper including the volume, issue and page numbers.

Link to publication

\footnotetext{
General rights rights.

- You may freely distribute the URL identifying the publication in the public portal. please follow below link for the End User Agreement:

www.umlib.nl/taverne-license

Take down policy

If you believe that this document breaches copyright please contact us at:

repository@maastrichtuniversity.nl

providing details and we will investigate your claim.
}

Copyright and moral rights for the publications made accessible in the public portal are retained by the authors and/or other copyright owners and it is a condition of accessing publications that users recognise and abide by the legal requirements associated with these

- Users may download and print one copy of any publication from the public portal for the purpose of private study or research.

- You may not further distribute the material or use it for any profit-making activity or commercial gain

If the publication is distributed under the terms of Article $25 \mathrm{fa}$ of the Dutch Copyright Act, indicated by the "Taverne" license above, 
Haalbaarheidsstudie

Regionale Ad-colleges (RAC's) Oost-Brabant en Zuidwest

In opdracht van de werkgroep RAC Zuidwest Nederland en RAC Oost Brabant

Eveline Sijbers

Frank Cörvers

\section{ROA Technical Report}

ROA-TR-2018/1

Researchcentrum voor Onderwijs en Arbeidsmarkt | ROA

Research Centre for Education and the Labour Market | ROA 
Haalbaarheidsstudie

Regionale Ad-colleges (RAC's) Oost-Brabant en Zuidwest

In opdracht van de werkgroep RAC Zuidwest Nederland en RAC Oost Brabant

\author{
Eveline Sijbers \\ Frank Cörvers
}

ROA-TR-2018/1

February 2018

Research Centre for Education and the Labour Market

Maastricht University

P.O. Box 616, 6200 MD Maastricht, The Netherlands

$\mathrm{T}+31433883647 \mathrm{~F}+31433884914$

secretary-roa-sbe@maastrichtuniversity.nl

www.roa.nl 


\section{Inhoudsopgave}

Pagina

Inleiding

1 Is er sprake van een duidelijk signaal vanuit het werkveld dat er behoefte is aan een Ad-opleiding? Om wat voor type opleiding gaat het dan en waaruit blijkt dat?

2 Kan deze behoefte aan een Ad-opleiding kwalitatief onderbouwd worden?

3 Van welke opleidingen in het $\mathrm{MBO}$ en $\mathrm{HBO}$ zal de nieuwe Ad-opleiding concurrentie ondervinden en wat is de huidige arbeidsmarktsituatie voor die opleidingen?

$4 \quad$ Wat zijn de verwachte arbeidsmarktperspectieven voor de nieuwe Ad-opleiding en voor de concurrerende opleidingen?

5 Hoe moet de Ad gepositioneerd worden ten opzichte van de andere opleidingen?

6 Is er sprake van een voldoende commitment vanuit het werkveld voor de nieuwe Ad-opleiding?

Conclusie

Bijlagen 


\section{Inleiding}

Er lijkt op grond van de verdeling in zowel capaciteiten van schoolverlaters en werkenden als in beloning op de arbeidsmarkt behoefte te zijn aan een substantieel extra uitstroomniveau tussen mbo niveau 4 en hbo bachelor in. Dat gat kan door Associate degree (Ad) opleidingen ingevuld worden. In lijn met het kabinetsbeleid, zoals uiteengezet in de Kamerbrief van Minister Bussemaker van 5 juni 2015 (kst-31288-473), wordt onderzocht of in twee regio's, te weten Zuidwest Nederland en Oost Brabant of de Ad-opleidingen zelfstandig kunnen worden ondergebracht in twee aparte onderwijscentra, zogeheten Regionale Ad-Colleges (RAC's), die gevestigd zouden kunnen worden in Den Bosch respectievelijk Bergen op Zoom.

De oprichting van de RAC's betekent een breuk met de huidige situatie, waarin een Ad-opleiding van twee jaar is gekoppeld aan eenzelfde vierjarige bachelor opleiding van de betreffende hogeschool. Als gevolg daarvan sluit een associate degree opleiding tot nog toe aan bij een bacheloropleiding, doorlopen Ad-studenten een propedeuse en zitten zij bij bachelor- studenten in de klas ('aanschuifonderwijs'). Het streven is om Ad-opleidingen met een duidelijk profiel voor studenten, werkgevers en de arbeidsmarkt op te zetten, losgekoppeld van de hbo bachelor opleidingen.

In deze factsheet worden de aanpak, de kosten en het tijdspad uiteengezet voor een haalbaarheidsstudie voor de business case van de twee RAC's. Om dit te onderzoeken wordt gekeken naar de arbeidsmarktsituatie van Ad-opleidingen die Avans Hogeschool en HZ University of Apllied Sciences overwegen aan te bieden. Aan deze Ad-opleidingen worden verwante opleidingen van de beroepsopleidende leerweg (bol) van mbo niveau 4 en hbo bachelor opleidingen gekoppeld voor verdere analyse. Voor deze opleidingen wordt met een kwalitatieve onderbouwing een oordeel gevormd van de arbeidsmarktpositie en het verwachte arbeidsmarktperspectief.

In het huidige onderzoek is gebruik gemaakt van verschillende databronnen:

- Jaarlijkse cijfers mbo-monitor, het onderzoek dat plaatsvindt onder de afgestudeerden van het mbo ruim één jaar na het verlaten van de opleiding. Voor elke opleiding wordt een gedetailleerd beeld over de arbeidsmarktsituatie van de afgestudeerden, waar ze terechtkomen, wat de vereisten zijn in de functie, of ze binnen hun vakgebied werken, welke competenties nodig zijn, of ze iets gemist hebben in de opleiding, of ze de opleiding opnieuw zouden kiezen en andere factoren geanalyseerd. Andere cijfers dan in deze factsheet zijn beschikbaar via de website van het ROA (www.roa.nl) onder het kopje 'School leaver survey statistics'.

- Jaarlijkse cijfers van de hbo-monitor, het onderzoek dat plaatsvindt onder de afgestudeerden, en levert vergelijkbare gegevens op als de mbo-Monitor. Andere cijfers dan in deze factsheet zijn beschikbaar via de website van het ROA (www.roa.nl) onder het kopje 'School leaver survey statistics'.

- De 2-jaarlijkse prognoses van het ROA over de toekomstige arbeidsmarktsituatie van bepaalde opleidingen. Op hbo-niveau worden ongeveer 35 opleidingstypen onderscheiden en op mbo-niveau ongeveer 30. Voor elk van deze opleidingstypen is 
bekend wat de huidige arbeidsmarktsituatie is, wat de verwachte situatie is in de komende 5 jaar of er veel of weinig vervanging met andere opleidingen plaatsvindt op de arbeidsmarkt, of het erg conjunctuurgevoelig is etc. Andere cijfers dan in deze factsheet zijn beschikbaar via de website van het ROA (www.roa.nl) onder het kopje 'labour market forecasts'.

- Het CBS presenteert via hun website (http://statline.cbs.nl/statweb/) eveneens gegevens over de instroom, doorstroom en uitstroom bij MBO en $\mathrm{HBO}$ opleidingen.

- SEO Economisch onderzoek presenteert eveneens cijfers over de arbeidsarktontwikkelingen van Ad-opleidingen. Het is daarom belangrijk om ook deze aanvullende gegevens bij uw onderbouwing te betrekken. ${ }^{1}$

Om de business case van de twee RAC's te onderzoeken wordt gekeken naar de Ad-opleidingen die men er op de korte en langere termijn wil aanbieden. Per Ad-opleiding wordt getracht een beeld gegeven van de arbeidsmarktrelevantie aan de hand van de volgende zes aandachtspunten ${ }^{2}$ :

1. Is er sprake van een duidelijk signaal vanuit het werkveld dat er behoefte is aan een Ad opleiding? Om wat voor type opleiding gaat het dan en waaruit blijkt dat?

2. Kan deze behoefte aan een Ad opleiding kwalitatief onderbouwd worden?

3. Van welke opleidingen in het mbo en hbo zal de nieuwe Ad-opleiding concurrentie ondervinden en wat is de huidige arbeidsmarktsituatie voor die opleidingen?

4. Wat zijn de verwachte arbeidsmarktperspectieven voor de nieuwe Ad opleiding en voor de concurrerende opleidingen?

5. Hoe moet de Ad gepositioneerd worden ten opzichte van de andere opleidingen?

6. Is er sprake van een voldoende commitment vanuit het werkveld voor de nieuwe Ad-opleiding?

De analyses om deze vragen te beantwoorden zijn, tenzij anders aangegeven, alle gebaseerd op vijfjaargemiddelden over de jaren 2010 tot en met 2014. Voor de verwante mbo opleidingen zijn alleen mbo bol-opleidingen van niveau 4 meegenomen, voor de verwante hbo opleidingen alleen hbo bachelor. Over individuele hbo- of mbo-opleidingen kunnen geen uitspraken worden gedaan, omdat de steekproef van de geselecteerde opleidingen te weinig respondenten heeft om betrouwbare resultaten per opleiding te kunnen presenteren. Daarom zijn de verwante opleidingen als cluster per domein geanalyseerd.

1. Hiervoor is gebruik gemaakt van het rapport M. Imandt (SEO Economisch Onderzoek), E. van den Berg (SEO Economisch Onderzoek), J. Mulder (ecbo), F. Verbeek (Kohnstamm Instituut), R. Petit (Kohnstamm Instituut), C. Meng (ROA), Klaar voor de groei? Monitor uitrol Associate degree, In opdracht van Ministerie van Onderwijs, Cultuur en Wetenschap, Amsterdam, oktober 2015.

2. Zie ROA (2011), Associate degree opleidingen en arbeidsmarktrelevantie, Een handleiding voor pilotronde 5, ROA Brochure, Universiteit Maastricht. 


\section{Is er sprake van een duidelijk signaal vanuit het werkveld dat er behoefte is aan een Ad-opleiding? Om wat voor type opleiding gaat het dan en waaruit blijkt dat?}

Voor de vervolgstappen van dit onderzoek hebben de werkgroepen aangegeven welke mbo bolopleidingen van niveau 4 en hbo bachelor opleidingen verwant zijn aan de Ad-opleidingen die men op het oog heeft voor de twee RAC's. De opleidingen die van de werkgroepen zijn ontvangen is opgeschoond en aangevuld, om zo een compleet mogelijke lijst met aan de Ad-opleidingen verwante opleidingen te verkrijgen. Deze lijst is weergegeven in bijlage 1.

Een dergelijke lijst van verwante opleidingen is van belang omdat de onderbouwing van de arbeidsmarktrelevantie hierop berust. De associate degree opleidingen zijn pas sinds 2013 een definitief onderdeel van het hoger beroepsonderwijs, en hierdoor is het aantal gediplomeerden van een bekostigde Ad-opleiding nog relatief laag. Uit het studiejaar 2012/2013 haalden 1.381 studenten een associate degree aan een bekostigde instelling (niet particulier), tegenover 59.246 die hun bachelor diploma behaalden. Hierdoor kan er bij Ad-gediplomeerden nog weinig betrouwbare informatie worden ingewonnen met betrekking tot hun succes op de arbeidsmarkt, laat staan na splitsing naar domein of opleiding. Een lijst met de arbeidsmarktpositie van afgestudeerden van verwante mbo 4 en hbo bachelor opleidingen biedt hier uitkomst, aangezien hiermee kan worden bepaald hoe succesvol een Ad-gediplomeerde op de arbeidsmarkt zou kunnen zijn. 


\section{Kan deze behoefte aan een Ad-opleiding kwalitatief onderbouwd worden?}

Er wordt op basis van arbeidsmarktgegevens gekeken of er een ruimte is voor mogelijke Adopleidingen voor de invulling van functies bij werkgevers. Ter aanvulling zou het georganiseerde bedrijfsleven in de betreffende branche moeten aangeven een herkenbaar nieuwe functie op Adniveau te willen creëren, en de behoefte aan de invulling van een dergelijke functie laten zien. Het is mogelijk om onderstaande cijfers via aanvullend onderzoek onder werkgevers verder te onderbouwen.

\section{Onder- of overbenutting gediplomeerden}

De behoefte aan een associate degree kan gezien worden als de mate waarin schoolverlaters van aan de Ad verwante opleidingen van mbo niveau 4 en hbo bachelor op een beroepsniveau gaan werken dat vergelijkbaar zou zijn met het Ad-niveau. Indicatoren die dat aangeven zijn bijvoorbeeld een grote onderbenutting van schoolverlaters van hbo bachelor (i.e. werken onder niveau) en een grote overbenutting van mbo-schoolverlaters niveau 4 (i.e. werken boven niveau).

\section{Definitie}

Werkzaam boven eigen niveau: Percentage afgestudeerden dat aangeeft dat voor de huidige functie een hoger opleidingsniveau werd vereist dan het eigen opleidingsniveau. Percentages van 0 tot $5 \%$ gelden als laag, van 5 tot $10 \%$ als gemiddeld en $10 \%$ of hoger gelden als hoog.

Werkzaam beneden eigen niveau: Percentage afgestudeerden dat aangeeft dat voor de huidige functie een lager opleidingsniveau werd vereist dan het eigen opleidingsniveau. Percentages van 0 tot $5 \%$ gelden als laag, van 5 tot $10 \%$ als gemiddeld en $10 \%$ of hoger gelden als hoog.

\begin{tabular}{|l|c|c|}
\hline & $\begin{array}{c}\text { MBO 4 verwante } \\
\text { opleidingen }\end{array}$ & $\begin{array}{c}\text { HBO BSc verwante } \\
\text { opleidingen }\end{array}$ \\
\hline $\begin{array}{c}\text { \% boven mbo niveau 4 } \\
\text { werkzaam }\end{array}$ & $\begin{array}{c}\text { \% werkzaam beneden hbo } \\
\text { bachelor niveau }\end{array}$ \\
\hline $\begin{array}{l}\text { Logistiek } \\
\text { Ad Logistiek management }\end{array}$ & $7 \%$ & $24 \%$ \\
\hline Agro foods & $3 \%$ & $20 \%$ \\
\hline $\begin{array}{l}\text { ICT } \\
\text { ICT-Beheer, AD Servicemanagement }\end{array}$ & $10 \%$ & $11 \%$ \\
\hline $\begin{array}{l}\text { Zorg } \\
\text { AD Management in de Zorg, AD Pedagogisch educatief medewerker }\end{array}$ & $2 \%$ & $43 \%$ \\
\hline $\begin{array}{l}\text { Techniek } \\
\text { AD Technische Bedrijfskunde, AD Maintenance Mechanics, AD } \\
\text { Engineering }\end{array}$ & $9 \%$ & $17 \%$ \\
\hline $\begin{array}{l}\text { Economie } \\
\text { AD Officemanagement, AD Onderneme, AD Vitaliteitsmanagementen } \\
\text { toerisme }\end{array}$ & $8 \%$ & $21 \%$ \\
\hline
\end{tabular}

Over het gehele mbo bol niveau 4 in de periode 2010-2014 is gemiddeld 5,5\% van de werkzame gediplomeerde schoolverlaters boven hun niveau werkzaam, en over het gehele hbo bachelor is gemiddeld $23,8 \%$ van de werkzame gediplomeerde schoolverlaters onder hun niveau werkzaam. In de bovenstaande tabel is te zien dat er bij logistiek, ICT, techniek en economie een gemiddeld percentage mbo niveau 4 gediplomeerden boven het niveau werkzaam is, maar er wel een hoog 
percentage hbo gediplomeerden beneden het niveau werkzaam is. Bij Agro foods en Zorg is een klein gedeelte van mbo niveau 4 gediplomeerden werkzaam boven het niveau, en juist een groot gedeelte van de hbo gediplomeerden onder het niveau werkzaam.

Een grote onderbenutting van schoolverlaters van hbo bachelor en/of grote overbenutting van mbo-schoolverlaters niveau 4 is een indicatie voor ruimte voor een associate degree op de arbeidsmarkt. Werken er veel mbo-schoolverlaters boven hun niveau, dat is dat een indicatie dat het zinvol kan zijn dat zij een aanvullende opleiding zoals een Ad-opleiding gaan volgen. Werken er veel schoolverlaters van hbo-bachelor onder hun niveau, dan zou dat ook kunnen betekenen dat een Ad-opleiding in plaats van een hbo-opleiding voldoende is voor de invulling van hun functie. Bij elk hbo domein is er sprake van een hoog aandeel dat onder hun niveau werkt. Wanneer dit gecombineerd wordt met de overbenutting van mbo niveau 4 gediplomeerden, valt te concluderen dat er vooral in de sector ICT ruimte is voor een associate degree. Daarnaast lijken de domeinen logistiek, techniek en economie ook ruimte te bieden voor een associate degree, met een gemiddelde overbenutting van mbo niveau 4 gediplomeerden. De domeinen agro foods en zorg hebben de laagste overbenutting van mbo niveau 4 gediplomeerden, maar desondanks kan hier ruimte zijn voor een associate degree vanwege de hoge onderbenutting van hbo bachelors.

\section{Aanvullende training en doorstroom}

Wanneer gediplomeerden van mbo niveau 4 nog aanvullende training volgen, is dit een indicatie dat mbo'ers bovenop de afgeronde mbo niveau 4 opleiding nog aanvullende scholing nodig hebben. De doorstroom naar het hbo kan een indicatie geven of er mogelijke problemen zijn in de aansluiting tussen mbo niveau 4 en het hbo die verhinderen dat mbo'ers doorstromen. Zowel veel aanvullende training als weinig doorstroom naar het hbo kan duiden op een arbeidsmarktbehoefte aan Ad'ers.

\section{Definitie}

Training: Percentage werkzame afgestudeerden dat aangeeft dat na het verlaten van de opleiding (dus in anderhalf jaar tijd) nog een aanvullende cursus of bedrijfsopleiding is gevolgd. Percentages tot $40 \%$ gelden als laag, van 40 tot $60 \%$ als gemiddeld en $60 \%$ of meer als hoog.

Doorstroom naar hbo: Percentage afgestudeerden dat na verlaten van de opleiding is doorgestroomd naar het hbo. Percentages van 0 tot $40 \%$ gelden als laag, van 40 tot $60 \%$ als gemiddeld en $60 \%$ of hoger gelden als hoog.

\begin{tabular}{|l|c|c|}
\hline & \multicolumn{2}{|c|}{ MBO 4 verwante opleidingen } \\
\hline & $\begin{array}{c}\text { \% aanvullende } \\
\text { training }\end{array}$ & $\begin{array}{c}\text { \% doorgestroomd } \\
\text { hbo }\end{array}$ \\
\hline $\begin{array}{l}\text { Logistiek } \\
\text { AD Logistiek management }\end{array}$ & $31 \%$ & $20 \%$ \\
\hline Agro food & $25 \%$ & $20 \%$ \\
\hline $\begin{array}{l}\text { ICT } \\
\text { SD Cross mediale communicatie, AD Business IT\& Management, AD ICT-Beheer, AD } \\
\text { Servicemanagement }\end{array}$ & $43 \%$ & $21 \%$ \\
\hline
\end{tabular}




\begin{tabular}{|c|c|c|}
\hline $\begin{array}{l}\text { Zorg } \\
\text { AD Management in de Zorg, AD Pedagogisch educatief medewerker }\end{array}$ & $54 \%$ & $15 \%$ \\
\hline $\begin{array}{l}\text { Techniek } \\
\text { AD Technische Bedrijfskunde, AD Maintenance Mechanics, AD Engineering }\end{array}$ & $54 \%$ & $22 \%$ \\
\hline $\begin{array}{l}\text { Economie } \\
A D \text { Officemanagement, } A D \text { Onderneme, } A D \text { Vitaliteitsmanagement en toerismen }\end{array}$ & $36 \%$ & $29 \%$ \\
\hline
\end{tabular}

Bovenstaande tabel laat zien dat voor de domeinen ICT, Zorg en Techniek de aanvullende training gemiddeld is, maar voor de domeinen Logistiek, Agro food en Economie is het percentage dat nog aanvullende training volgt laag. De doorstroom naar hbo opleidingen is voor elk domein laag, met de minste doorstroom bij het domein Zorg en de meeste bij het domein Economie.

Voor de domeinen ICT, Zorg en Techniek volgt uit de combinatie van een gemiddeld aandeel dat aanvullende training nodig heeft met aan lage doorstroom naar het hbo, een arbeidsmarktbehoefte aan associate degrees. Voor de domeinen Logistiek, Agro foods en Economie is er echter door het lage percentage dat aanvullende training minder aanleiding om een associate degree aan te bieden.

\section{Upgrading}

Een andere manier om de behoefte aan een Ad-opleiding kwalitatief te onderbouwen, is door te kijken naar verschuivingen in de functie-eisen binnen beroepen. In sommige beroepen is sprake van upgrading, dat wil zeggen een verhoging van de opleidingseisen van werkgevers. Dit is bijvoorbeeld af te lezen uit een toegenomen aandeel hbo'ers in deze beroepen. Als er sprake is van een verhoging van het aandeel hbo'ers in mboberoepen of een verlaging van mbo'ers in hbo-beroepen, dan kan dat gezien worden als een indicatie dat er behoefte is aan een tussenniveau van de Ad-opleiding. In bijlage 2 van deze factsheet is een overzicht gegeven van de beroepen die van belang zijn voor de Adopleidingen in de RAC's van Avans Hogeschool.

\section{Definitie}

Upgrading: het verhogen van opleidingseisen in een beroep, vanwege de toenemende complexiteit van de werkzaamheden. We meten dat voor de MBO- en HBO-beroepen door te kijken naar de verschuiving in de verhouding tussen de aandelen MBO'ers en HBO'ers in die beroepen in de periode 2005-2009 en de periode 2010-2015.

Die verschuiving wordt als volgt getypeerd:

- Sterke upgrading: verandering van minimaal $10 \%$ stijging in verhouding $\mathrm{HBO} / \mathrm{MBO}$

- Upgrading: verandering van 5 tot $10 \%$ stijging in verhouding $\mathrm{HBO} / \mathrm{MBO}$

- Constant: verandering tussen $-5 \%$ en $+5 \%$ in verhouding $\mathrm{HBO} / \mathrm{MBO}$

- Downgrading: verandering $-5 \%$ tot $-10 \%$, ofwel 5 tot $10 \%$ daling in verhouding $\mathrm{HBO} / \mathrm{MBO}$ - Sterke downgrading: verandering boven $-10 \%$, ofwel $10 \%$ daling in verhouding $\mathrm{HBO} / \mathrm{MBO}$

De 80\% meest voorkomende beroepen gebaseerd op de aan de Ad-opleidingen verwante mbo en hbo opleidingen zijn hiervoor gebruikt. De volledige lijst staat in bijlage 2 . Hieronder zijn de resultaten grofweg samengevat per domein. 


\begin{tabular}{|l|c|}
\hline & Upgrading \\
\hline $\begin{array}{l}\text { Logistiek } \\
\text { AD Logistiek management }\end{array}$ & constant /upgrading \\
\hline Agro foods & upgrading \\
\hline $\begin{array}{l}\text { ICT } \\
A D \text { Cross mediale communicatie, AD Business IT\& Management, AD ICT-Beheer, AD Servicemanagement } \\
\text { Zorg } \\
\text { AD Management in de Zorg, AD Pedagogisch educatief medewerker }\end{array}$ & upgrading \\
\hline $\begin{array}{l}\text { Techniek } \\
\text { AD Technische Bedrijfskunde, AD Maintenance Mechanics, AD Engineering }\end{array}$ & constant / downgrading \\
\hline $\begin{array}{l}\text { Economie } \\
\text { AD Officemanagement, AD Ondernemen, AD Vitaliteitsmanagement en toerisme }\end{array}$ & Upgrading \\
\hline
\end{tabular}

Uit de tabel is af te lezen dat er bij de domeinen Agro, ICT en Techniek overwegend sprake is van upgrading in de bijbehorende beroepen. Voor de domeinen Logistiek en Economie is er een gemengd beeld van beroepen waarin het opleidingsniveau constant blijft en beroepen waar sprake is van upgrading. Voor het domein Zorg is er een gemengd beeld van een constant opleidingsniveau en een downgrading van beroepen, ofwel een steeds lager opleidingsniveau binnen dezelfde beroepsgroep.

Uit deze tabel blijkt dat er verschillende beroepen zijn binnen de sectoren Agro foods, ICT en Techniek waar er steeds meer hbo gediplomeerden ten opzichte van mbo gediplomeerden bevinden. Deze upgrading lijkt een indicatie voor de behoefte aan een Ad-opleiding in deze domeinen. De sectoren Logistiek en Economie laten een gemengd beeld zien tussen beroepen die een constant opleidingsniveau behouden en beroepen die een steeds hoger aandeel hbo'ers ten opzichte van mbo'ers handhaven. Hieruit blijkt dat bij sommige beroepen wel vraag kan zijn naar Ad'ers, en bij andere beroepen minder. Het domein Zorg laat een gemengd beeld van constant en downgrading zien, ofwel het niveau blijft gelijk of verschuift naar steeds meer mbo'ers. Dit kan een indicatie zijn van een mindere behoefte aan een associate degree in dit domein.

Hierbij moet wel vermeld worden dat deze tabel met enige vrij interpretatie tot stand is gekomen. Beroepen zijn namelijk niet rechtlijnig te koppelen aan een opleidingsdomein. Gediplomeerden belanden lang niet altijd in het beoogde beroep dat volgens het curriculum aan hun opleidingsdomein is gekoppeld. Zo belandt gemiddeld $22 \%$ van de hbo gediplomeerden en $24 \%$ van de mbo niveau 4 gediplomeerden in een functie die niet verwant is aan hun opleidingsdomein. 


\section{Van welke opleidingen in het $\mathrm{MBO}$ en $\mathrm{HBO}$ zal de nieuwe Ad- opleiding concurrentie ondervinden en wat is de huidige arbeidsmarktsituatie voor die opleidingen?}

Een volgend aandachtspunt betreft het bepalen van de huidige arbeidsmarktposities van de opleidingen waarmee de Ad-opleidingen mogelijk kunnen concurreren. De afgestudeerden van een Ad-opleiding zullen zich immers deels op dezelfde markt aanbieden als afgestudeerden van de bestaande mbo of bachelor opleidingen. Een hoge werkloosheid of een slechte verticale aansluiting kan duiden op een slechte arbeidsmarktpositie van opleidingen die concurreren op hetzelfde segment op de arbeidsmarkt als de nieuwe Ad-opleiding. Het ligt dan voor de hand dat de afgestudeerden van de Ad-opleiding met eenzelfde slechte arbeidsmarktsituatie zullen worden geconfronteerd.

\section{Werkloosheid en verticale aansluiting}

Om de arbeidsmarktpositie te bepalen wordt gebruik gemaakt van zowel de werkloosheid als de verticale aansluiting. De opleidingen verwant aan de Ad-opleidingen zijn gebruikt als maatstaf voor de arbeidsmarktpositie voor de Ad-opleidingen.

\section{Definitie}

Werkloosheid: aandeel van de werkloze beroepsbevolking in de totale beroepsbevolking. Percentages tot $4 \%$ gelden als laag, 4 tot $6 \%$ als gemiddeld en $6 \%$ of meer als hoog. Totale beroepsbevolking: personen die tot de werkzame beroepsbevolking behoren of tot de werkloze beroepsbevolking behoren.

Werkloze beroepsbevolking: personen die actief op zoek zijn naar een baan (van twaalf uur of meer per week), daarvoor beschikbaar zijn en geen werk hebben of een baan hebben van minder dan twaalf uur per week.

Verticale aansluiting: percentage afgestudeerden dat werk heeft waarvoor minimaal het eigen opleidingsniveau is vereist. Percentages tot $75 \%$ gelden als laag, 75 tot $85 \%$ als gemiddeld en $85 \%$ of meer als hoog.

\begin{tabular}{|l|c|c|c|c|}
\hline & \multicolumn{2}{|c|}{ Verwante mbo-4 opleiding } & \multicolumn{2}{|c|}{$\begin{array}{c}\text { Verwante hbo bachelor } \\
\text { opleiding }\end{array}$} \\
\hline & $\begin{array}{c}\% \\
\text { werkloos }\end{array}$ & $\begin{array}{c}\% \text { werkzaam } \\
\text { minimaal eigen } \\
\text { niveau }\end{array}$ & $\begin{array}{c}\% \\
\text { werkloos }{ }^{2}\end{array}$ & $\begin{array}{c}\% \text { werkaam } \\
\text { minimaal eigen } \\
\text { niveau }\end{array}$ \\
\hline $\begin{array}{l}\text { Logistiek } \\
\text { AD Logistiek management }\end{array}$ & $10 \%$ & $63 \%$ & $7 \%$ & $76 \%$ \\
\hline $\begin{array}{l}\text { Agro foods } \\
\text { ICT }\end{array}$ & $15 \%$ & $83 \%$ & $6 \%$ & $80 \%$ \\
\hline $\begin{array}{l}\text { AD Cross mediale commugement, AD ICT-Beheer, AD } \\
\text { Servicemanagement }\end{array}$ & $15 \%$ & $79 \%$ & $3 \%$ & $89 \%$ \\
\hline $\begin{array}{l}\text { Zorg } \\
\text { AD Management in de Zorg, AD Pedagogisch } \\
\text { educatief medewerker }\end{array}$ & $6 \%$ & $87 \%$ & $5 \%$ & $57 \%$ \\
\hline
\end{tabular}

3. Meting ongeveer 1,5 jaar na afstuderen. 


\begin{tabular}{|l|c|c|c|c|}
\hline $\begin{array}{l}\text { Techniek } \\
\text { AD Technische Bedrijfskunde, AD Maintenance } \\
\text { Mechanics, AD Engineering }\end{array}$ & $3 \%$ & $79 \%$ & $4 \%$ & $83 \%$ \\
\hline $\begin{array}{l}\text { Economie } \\
\begin{array}{l}\text { AD Officemanagement, AD Ondernemen, } A D \\
\text { Vitaliteitsmanagement en toerisme }\end{array}\end{array}$ & $12 \%$ & $64 \%$ & $8 \%$ & $80 \%$ \\
\hline
\end{tabular}

Voor de verwante mbo 4 opleidingen is er sprake van een lage werkeloosheid bij het domein Techniek, een gemiddelde werkloosheid bij het domein Zorg en een hoge werkloosheid bij de andere domeinen. Voor de verwante hbo bachelor opleidingen is er sprake van een lage werkloosheid bij wederom het domein Techniek, maar ook bij het domein ICT. Van een gemiddelde werkloosheid is sprake bij het domein Zorg en Agro foods, en een hoge werkloosheid bij de andere domeinen. De verticale aansluiting voor mbo 4 gediplomeerden is laag bij het domein Logistiek en Economie, gemiddeld bij de domeinen Techniek, ICT en Agro foods en hoog bij het domein Zorg. Voor hbo bachelor gediplomeerden is de verticale aansluiting laag voor het domein Zorg, gemiddeld voor de domeinen Economie, Techniek, Logistiek en Agro foods en hoog voor het domein ICT.

De hoogte van de werkloosheidscijfers en verticale aansluitingen van de verwante opleidingen moeten tevens worden gezien in het licht van de totale gemiddelde werkloosheid onder schoolverlaters van mbo en hbo. Deze getallen zijn terug te vinden in bijlage 3.

Alles samen genomen ziet het er voor de gediplomeerden van Ad-opleidingen uit de domeinen Logistiek en Economie het slechtst uit. Voor beide domeinen geldt dat er een hoge werkloosheid is onder verwante opleidingen, en deze is ook hoger dan het gemiddelde van de vergelijkbare sector. De verticale aansluiting is laag voor het mbo en gemiddeld voor het hbo. Hierdoor is de verwachting dat Ad'ers uit deze domeinen niet al te beste arbeidsmarktperspectieven zullen hebben. Voor Ad-gediplomeerden van de domeinen ICT en Zorg is er een gemengd beeld. Bij de ICT is de werkloosheid hoog bij het mbo (en hoger dan het sectorgemiddelde) maar laag (en lager dan het sectorgemiddelde) bij het hbo. Tevens is de verticale aansluiting beter bij het hbo dan het mbo. Een mogelijkheid zou zijn om de opleiding te focussen op de beroepen op hbo-niveau dan op mbo, omdat daar de arbeidsmarktperspectieven gunstig zijn. Een min of meer tegenovergesteld beeld is te zien bij het domein Zorg, waar de verticale aansluiting slechter is bij het hbo. Het zou hier dus een mogelijkheid zijn om de focus iets meer te leggen op mboplusberoepen dan op hbomin- beroepen. Voor het domein Agro foods geld dat de werkloosheid voor de verwante opleidingen vrij hoog is (en ook hoger dan het sectorgemiddelde) en de aansluiting gemiddeld. Hierdoor zijn de kansen op werk naar verwachting slechter voor Ad-gediplomeerden uit dit domein, maar is de kans op werk op niveau gemiddeld. Voor het domein Techniek geld dat er gunstige arbeidsmarktkansen liggen voor Ad'ers. De werkloosheid voor de verwante opleidingen is laag, en ook lager dan het sectorgemiddelde. De verticale aansluiting is gemiddeld. Hierdoor zouden Ad-gediplomeerden uit dit domein zonder veel moeite een baan op niveau moeten kunnen vinden.

\section{Regionale arbeidsmarktsituatie}

De plannen voor de RAC's wijzen momenteel op een vestiging in Den Bosch respectievelijk Bergen op Zoom. Daarom is het van belang om te kijken hoe de arbeidsmarktsituatie in deze arbeidsmarktregio's is vergeleken met de landelijke arbeidsmarktsituatie. Voor het RAC in Den Bosch zijn de arbeidsmarktregio's Noordoost Brabant en Midden-Brabant meegenomen, voor het 
RAC in Bergen op Zoom zijn de arbeidsmarktregio's West-Brabant en Zeeland meegenomen. Hier moet bij vermeld worden dat door te selecteren op alleen de verwante opleidingen en op de arbeidsmarktregio's, er soms relatief lage aantallen respondenten overblijven. Onderstaande resultaten zijn dus een hulpmiddel, maar er dient niet teveel gewicht aan gehangen te worden.

\section{Definities}

Arbeidsmarktregio voor RAC Bergen op Zoom: Betreft de arbeidsmarktregio West Brabant, gedefinieerd als de plaatsen Breda, Bergen op Zoom, Roosendaal, Aalburg, Drimmelen, Etten-Leur, Geertruidenberg, Halderberge, Moerdijk, Oosterhout, Rucphen, Steenbergen, Werkendam, Woensdrecht, Woudrichem en Zundert. Daarnaast bevat het de arbeidsmarktregio Zeeland, waaronder de plaatsen Middelburg, Vlissingen, Terneuzen, Goes,Borsele, Hulst, Kapelle, , NoordBeveland, Reimerswaal, Schouwen-Duiveland, Sluis, Tholen, Veere en vallen.

Arbeidsmarktregio voor RAC Den Bosch: Bevat de arbeidsmarktregio Noordoost Brabant, gedefinieerd als de plaatsen 's-Hertogenbosch, Oss, Veghel, Boxmeer, Uden, Bernheze, Cuijk, Boekel, Boxtel, Grave, Haaren, Landerd, Mill en Sint Hubert, Schijndel, Sint Anthonis, SintMichielsgestel, Sint-Oedenrode, en Vught. Daarnaast bevat dit de arbeidsmarktregio MiddenBrabant, waaronder de plaatsen Tilburg, Waalwijk, Heusden, Hilvarenbeek, Oisterwijk, BaarleNassau, Alphen-Chaam, Dongen, Gilze en Rijen, Goirle en Loon op Zand vallen.

\begin{tabular}{|c|c|c|c|c|}
\hline & \multicolumn{2}{|c|}{ Verwante mbo-4 opleiding } & \multicolumn{2}{|c|}{ Verwante hbo bachelor opleiding } \\
\hline & $\begin{array}{c}\text { \% Werkloos } \\
\text { arbeidsmarktregio } \\
\text { Den Bosch i.v.t. } \\
\text { landelijk }\end{array}$ & $\begin{array}{c}\text { \% Werkloos } \\
\text { arbeidsmarktregio } \\
\text { Bergen op Zoom } \\
\text { i.v.t. landelijk } \\
\end{array}$ & $\begin{array}{l}\% \text { Werkloos } \\
\text { arbeidsmarktregio } \\
\text { Den Bosch }{ }^{5}\end{array}$ & $\begin{array}{c}\text { \% Werkloos } \\
\text { arbeidsmarktregio } \\
\text { Bergen op Zoom } \\
\text { i.v.t. landelijk }\end{array}$ \\
\hline $\begin{array}{l}\text { Logistiek } \\
A D \text { Logistiek management }\end{array}$ & Lager & (Veel) hoger & (Veel) hoger & Hoger \\
\hline Agro foods & Lager & Lager & Lager & Lager \\
\hline $\begin{array}{l}\text { ICT } \\
\text { AD Cross mediale communicatie, } \\
\text { AD Business IT\& Management, } A D \\
\text { ICT-Beheer, } A D \\
\text { Servicemanagement }\end{array}$ & Lager & Lager & Gelijk & Lager \\
\hline $\begin{array}{l}\text { Zorg } \\
\text { AD Management in de Zorg, } A D \\
\text { Pedagogisch educatief } \\
\text { medewerker }\end{array}$ & Hoger & Lager & Gelijk & Lager \\
\hline $\begin{array}{l}\text { Techniek } \\
\text { AD Technische Bedrijfskunde, } A D \\
\text { Maintenance Mechanics, } A D \\
\text { Engineering }\end{array}$ & Lager & Lager & Gelijk & Lager \\
\hline $\begin{array}{l}\text { Economie } \\
A D \text { Officemanagement, } \\
A D \text { Ondernemen, } A D \\
\text { Vitaliteitsmanagementen }\end{array}$ & Lager & (Veel) hoger & Lager & Lager \\
\hline
\end{tabular}

4. Meting ongeveer 1,5 jaar na afstuderen.

5. Meting ongeveer 1,5 jaar na afstuderen. 
Hieruit is af te lezen dat voor de arbeidsmarktregio Den Bosch de verwante mbo opleidingen op bijna alle domeinen een lager werkloosheidspercentage hebben dan het landelijk gemiddelde. De enige uitzondering is het domein Zorg, waar het werkloosheidspercentage in arbeidsmarktregio Den Bosch hoger is dan landelijk. Bij de verwante hbo opleidingen is het werkloosheidspercentage vaak hetzelfde als landelijk, behalve bij de domeinen Economie en Agro foods waar het werkloosheidspercentage lager is dan het landelijk. Daarnaast is heeft hier het domein Logistiek een hoger werkloosheidspercentage dan het landelijk. Voor de arbeidsmarktregio Bergen op Zoom valt uit te tabel af te lezen dat voor veel domeinen de verwante mbo opleidingen een lager werkloosheidspercentage hebben als landelijk, met uitzondering van de domeinen Economie en Logistiek, waar het werkloosheidspercentage (veel) hoger ligt dan het landelijk. Bij de verwante hbo opleidingen is veelal een lager werkloosheidspercentage dan het landelijke, behalve bij Logistiek (hoger dan het landelijk).

Hieruit kan voorzichtig gesteld worden dat er voor de domeinen Agro foods, ICT en Techniek het in beide arbeidsmarktregio's goed doen op de arbeidsmarkt, waardoor gediplomeerden van een Adopleiding hier succesvol zouden kunnen zijn. Het domein Zorg heeft een gunstigere arbeidsmarktsituatie in Bergen op Zoom dan in Den Bosch, terwijl het domein Economie precies andersom gunstigere werkloosheidscijfers heeft in regio Den Bosch dan Bergen op Zoom. Het domein Logistiek heeft over het algemeen slechtere arbeidsmarktsituatie in deze regio's dan landelijk (met uitzondering voor mbo 4 verwante opleidingen in regio Den Bosch). 


\section{Wat zijn de verwachte arbeidsmarktperspectieven voor de nieuwe Ad-opleiding en voor de concurrerende opleidingen?}

Het is belangrijk om niet alleen te kijken naar de huidige arbeidsmarktpositie van verwante mbo 4 en hbo bachelor opleidingen, maar ook na te gaan wat de verwachte arbeidsmarktperspectieven zijn voor de sector waarvoor de boogde Ad opleiding voorbereidt. De arbeidsmarktperspectieven van een opleidingstype worden samengevat in de Indicator Toekomstig Arbeidsmarktperspectief (ITA). Het toekomstig arbeidsmarktperspectief geeft de verhouding tussen aanbod en vraag naar afgestudeerden voor een opleidingstype weer in de betreffende prognoseperiode. Het volledige overzicht is weergegeven in bijlage 4 .

\section{Definitie}

Indicator Toekomstig Arbeidsmarktperspectief (ITA): de verhouding tussen enerzijds de verwachte arbeidsmarktinstroom van afgestudeerden, het aantal kortdurend werklozen en anderzijds de verwachte baanopeningen en de passieve substitutievraag. Naarmate de waarde van de indicator hoger is wordt het perspectief slechter. Bij de typering worden de volgende categorieën onderscheiden: slecht, matig, redelijk, goed en zeer goed.

Arbeidsmarktinstroom van afgestudeerden: het aanbod van nieuwe arbeidskrachten op de arbeidsmarkt, bepaald door de uitstroom van schoolverlaters uit het onderwijs. Kortdurend werklozen: personen die korter dan één jaar werkloos zijn. Baanopeningen: de totale vraag naar nieuwkomers gebaseerd op de positieve uitbreidingsvraag en de vervangingsvraag.

\begin{tabular}{|l|c|c|c|c|}
\hline & $\begin{array}{c}\text { Verwante mbo } \\
\text { domeinen }\end{array}$ & ITA & $\begin{array}{c}\text { Verwante hbo } \\
\text { domeinen }\end{array}$ & ITA \\
\hline Agro foods & $\begin{array}{c}\text { mbo 4 voedsel, } \\
\text { natuur en milieu }\end{array}$ & Goed & Hbo chemie & Zeer goed \\
\hline & & $\begin{array}{c}\text { Hbo natuur en } \\
\text { milieu }\end{array}$ & Redelijk \\
\hline
\end{tabular}

Voor agro foods is te zien dat de ITA's tussen redelijk en zeer goed liggen, waardoor de verwachte arbeidsmarktperspectieven voor dit domein gemiddeld goed zijn. Dat betekent dat een Ad opleiding weinig concurrentie van deze opleidingen zal ondervinden, en zelf naar verwachting ook goede toekomstige arbeidsmarktperspectieven heeft.

Samengevat per domein is de verwachting dat voor Ad'ers uit het domein Logistiek de arbeidsmarktperspectieven slecht zijn, en voor Ad'ers uit het domein Zorg matig. Voor het gehele domein Agro foods zijn de arbeidsmarktperspectieven goed. Bij de overige domeinen wisselt het per opleidingsniveau. Voor de domeinen Techniek en ICT geldt dat de arbeidsmarktperspectieven voor het mbo slechter zijn dan voor het hbo. Hier zou eventueel een oplossing liggen in het verzwaren van het hbo aandeel van de Ad-opleiding. Voor het domein Economie zijn juist de arbeidsmarktperspectieven voor het mbo beter dan voor het hbo, waarbij een eventuele oplossing zou liggen in het iets meer verschuiven van de inhoud van de Ad-opleiding in de richting van de verwante mbo opleidingen. 


\section{Hoe moet de Ad gepositioneerd worden ten opzichte van de andere opleidingen?}

Ad-alumni hebben vaker een baan voorafgaand of tijdens de studie, zijn gemiddeld wat ouder en doen vaker een opleiding in deeltijd dan hbo bachelor en mbo niveau 4 studenten. De arbeidsmarktpositie van een Ad-gediplomeerde lijkt qua zoekduur, werkloosheid en salaris het meest op die van een mbo niveau 4 gediplomeerde. De arbeidsmarktpositie van een Ad'er lijkt echter wel een stuk steviger te zijn in vergelijking met een mbo 4 of een hbo bachelor gediplomeerden. De Ad'ers zijn minder vaak werkloos, heeft vaker een vast dienstverband en een hoger salaris dan de mbo'ers of hbo'ers. Een kleine helft van de Ad-alumni geeft aan dat de functie en/of arbeidsvoorwaarden zijn veranderd door het volgen van de Ad. Hier moet wel de voetnoot bij geplaatst worden dat het arbeidsmarktperspectief van een Ad'er niet altijd vergeleken kan worden met een mbo'er of hbo'er. De studenten aan een Ad-opleiding zijn veelal werkenden die in overleg met hun leidinggevende gekozen hebben voor het volgen van een Ad-opleiding.

Ook moet vermeld worden dat de personen die aan een Ad-opleiding deelnemen, deze opleiding veelal volgen naast hun baan. Dit kan mede het lage percentage werklozen verklaren. Maar liefst $21 \%$ doet een duale Ad-opleiding (werken en leren tegelijk), en nog eens $51 \%$ in deeltijd. Veel deeltijd Ad'ers hebben waarschijnlijk eveneens al een baan tijdens de opleiding.

Van de Ad-gediplomeerden is een flink gedeelte duaal aan het studeren, ofwel aan het leren tijdens zijn baan (21\%). Van de helft die aangeeft in deeltijd te studeren (51\%) valt ook te verwachten dat een groot gedeelte al werkzaam is, maar een opleiding voor eigen kosten of uit eigen belangstelling volgt naast de baan. Slechts $27 \%$ van de Ad-gediplomeerden heeft voltijd gestudeerd. Bij het hbo studeert slechts $3 \%$ duaal en $18 \%$ in deeltijd. Hierdoor valt het te verwachten dat Ad-gediplomeerden vaak al een baan hebben en tevens vaak in een hogere salarisschaal zitten dan hbo-gediplomeerden die nog moeten zoeken naar een startersfunctie.

\begin{tabular}{|l|l|l|l|}
\hline & \% voltijd & \% deeltijd & \% duaal \\
\hline Ad-gediplomeerden & $27 \%$ & $51 \%$ & $21 \%$ \\
\hline $\begin{array}{l}\text { Hbo bachelor } \\
\text { qediplomeerden }\end{array}$ & $79 \%$ & $18 \%$ & $3 \%$ \\
\hline
\end{tabular}

\section{Arbeidsmarktpositie en doorstroom associate degree opleidingen}

Van belang is dat een Ad-opleiding een opstap kan zijn, en veel gevallen al is, naar een bacheloropleiding. Bij de onderbouwing van een Ad-aanvraag moet zowel duidelijk zijn welke mogelijkheden een Ad biedt op de arbeidsmarkt als de mogelijkheden voor een vervolgopleiding en verdere scholing. De Ad dient de doorstroom te ondersteunen naar een vervolg aan een bacheloropleiding, zelfs als er in de richting van de Ad geen bachelor bestaat. Het doorstroomperspectief staat in beginsel los van het arbeidsmarktperspectief van een Adopleiding, maar verbreedt uiteraard wel de horizon van Ad-afgestudeerden. 
Deze cijfers zijn alleen beschikbaar over alle Ad-gediplomeerden samen. Wanneer er gesplitst wordt naar opleiding blijven er te weinig respondenten over om betrouwbare uitspraken over te doen.

\section{Definitie}

Werkloosheid: aandeel van de werkloze beroepsbevolking in de totale beroepsbevolking. Percentages tot $4 \%$ gelden als laag, 4 tot $6 \%$ als gemiddeld en $6 \%$ of meer als hoog. Doorstroom naar hbo: Percentage afgestudeerden dat na verlaten van de opleiding is doorgestroomd naar het HBO. Percentages van 0 tot $40 \%$ gelden als laag, van 40 tot $60 \%$ als gemiddeld en $60 \%$ of hoger gelden als hoog.

Tevredenheid aansluiting: Percentage afgestudeerden dat aangeeft de aansluiting tussen de vooropleiding en vervolgopleiding goed te vinden.

Tevredenheid voorbereiding: Percentage afgestudeerden dat aangeeft de voorbereiding op de vervolgopleiding goed te vinden.

\begin{tabular}{|l|l|l|l|l|}
\hline & \% Werkloos & \% Doorstroom hbo & $\begin{array}{l}\text { \% (zeer) tevreden } \\
\text { over aansluiting AD } \\
\text { op HBO }\end{array}$ & $\begin{array}{l}\text { \% van mening AD } \\
\text { goede voorbereiding } \\
\text { op HBO }\end{array}$ \\
\hline Ad-gediplomeerden & $4 \%$ & $75 \%$ & $73 \%$ \\
\hline
\end{tabular}

Uit deze tabel blijkt dat een laag percentage werkloos is, wat hierboven ook al besproken is. Daarnaast stroomt ongeveer een kwart door naar een hbo opleiding. Dit staat voor een lage doorstroom. De tevredenheid over de aansluiting en de voorbereiding is echter wel hoog: maar liefst driekwart is hier tevreden over.

De Ad-opleidingen dienen geschikt te zijn voor doorstroom naar een hbo bachelor opleiding, en deze ook te steunen. Uit bovenstaande cijfers blijkt dus dat driekwart van de gediplomeerden niet doorstroomt naar een hbo bachelor opleiding, maar wanneer ze dit doen wel overwegend tevreden zijn over de aansluiting en voorbereiding op de vervolgopleiding. Er lijkt dus geen aanwijzing te zijn op een moeilijke doorstroom naar het hbo.

\section{Competentietekort mbo schoolverlaters}

Meer algemeen lijkt het voor de inrichting van een RAC ook zinvol te zijn om te kijken naar waar het bij werkzame mbo-schoolverlaters van niveau 4 aan schort wat betreft hun generieke en specifieke competenties. Gegevens over competenties in de Ad-opleidingen aan RAC's kunnen bijvoorbeeld richting geven aan modules in het curriculum die door alle Ad-studenten aan een RAC worden gevolgd, en kan op deze wijze bijdragen aan een duidelijker profiel en een heldere didactische basis voor de Ad-opleidingen aan een RAC.

\section{Definitie}

Tekort persoonlijke vaardigheden: Een hoger vereist niveau in hun huidige functie dan beheersing van de vaardigheden zelfstandigheid, initiatief/creativiteit, aanpassingsvermogen en nauwkeurigheid/zorgvuldigheid.

Tekort geavanceerde vaardigheden: Een hoger vereist niveau in hun huidige functie dan beheersing van de vaardigheden inzicht in informatie- en communicatietechnologie, overdragen van kennis, 
plannen, coördineren en organiseren van activiteiten, contactuele vaardigheden en werken in teamverband.

Tekort begrijpende vaardigheden: Een hoger vereist niveau in hun huidige functie dan beheersing van de vaardigheden toepassen kennis en technieken in de praktijk, het oplossen van problemen en vakkennis.

\begin{tabular}{|c|c|c|c|}
\hline & \multicolumn{3}{|c|}{ Verwante mbo niveau 4 opleidingen } \\
\hline & $\begin{array}{c}\text { Tekort } \\
\text { persoonlijke } \\
\text { vaardigheden }\end{array}$ & $\begin{array}{c}\text { Tekort } \\
\text { geavanceerde } \\
\text { vaardigheden }\end{array}$ & $\begin{array}{c}\text { Tekort } \\
\text { begrijpende } \\
\text { vaardigheden }\end{array}$ \\
\hline $\begin{array}{l}\text { Logistiek } \\
\text { AD Logistiek management }\end{array}$ & $29 \%$ & $28 \%$ & $28 \%$ \\
\hline Agro foods & $40 \%$ & $38 \%$ & $20 \%$ \\
\hline $\begin{array}{l}\text { ICT } \\
\text { AD Cross mediale communicatie, AD Business IT\& } \\
\text { Management, AD ICT-Beheer, ADServicemanagement }\end{array}$ & $20 \%$ & $26 \%$ & $22 \%$ \\
\hline $\begin{array}{l}\text { Zorg } \\
\text { AD Management in de Zorg, AD Pedagogisch educatief } \\
\text { medewerker }\end{array}$ & $29 \%$ & $30 \%$ & $36 \%$ \\
\hline $\begin{array}{l}\text { Techniek } \\
\text { AD Technische Bedrijfskunde, AD Maintenance Mechanics, } \\
A D \text { Engineering }\end{array}$ & $31 \%$ & $29 \%$ & $32 \%$ \\
\hline $\begin{array}{l}\text { Economie } \\
A D \text { Officemanagement, } A D \text { Ondernemen, } A D \\
\text { Vitaliteitsmanagement en toerisme }\end{array}$ & $26 \%$ & $22 \%$ & $26 \%$ \\
\hline
\end{tabular}

Bij verwante mbo niveau 4 schoolverlaters blijkt dat 20 tot $40 \%$ een tekort aan persoonlijke vaardigheden rapporteert. Hierbij zit het grootste tekort aan agro food verwante mbo opleidingen, en het minste tekort bij de aan ICT verwante opleidingen. Daarnaast rapporteert 22 tot $38 \%$ een tekort aan geavanceerde vaardigheden, waarbij het minste tekort voorkomt aan het domein economie verwante mbo opleidingen en het grootste bij aan agro foods verwante opleidingen. Een tekort aan begrijpende vaardigheden komt bij 20 tot 36\% voor, waarbij wederom de ICT domein gerelateerde opleidingen het laagste tekort aan vaardigheden afleveren en Zorg domein gerelateerde opleidingen het hoogste.

Het lijkt voor Ad-opleidingen zinvol om competenties mee te nemen in hun opleidingsplan. Uit bovenstaande gegevens blijkt dat verschillende competenties tekort schieten bij mbo niveau 4 gediplomeerden, voor elk bestaand domein. De aandacht voor deze competenties in de Adopleidingen aan RAC's kan dus het beste aan alle Ad-studenten aan een RAC worden gegeven, ongeacht in welk domein of opleiding ze studeren.

\section{Mogelijkheid cross-overs}

In sommige gevallen kan het gunstig uitpakken om het curriculum van verschillende Adopleidingen gedeeltelijk te laten overlappen. De Ad-opleidingen bevinden zich nog in een beginfase, wat kan leiden tot kleinere klassen per opleiding. Uit bovenstaande tabel bleek al dat 
veel mbo niveau 4 gediplomeerden aangeven een tekort in competenties te hebben, en dat een specifieke aandacht voor het ontwikkelen en beheersen van deze competenties aan te raden is. Omdat deze competenties voor elke Ad-opleiding van toepassing zijn, zouden cross-over modules bij meerdere opleidingen doelmatig kunnen zijn. 


\section{Is er sprake van een voldoende commitment vanuit het werkveld voor de nieuwe Ad-opleiding?}

Voor het bepalen van de arbeidsmarktrelevantie is het belangrijk dat er duidelijke signalen zijn van werkgevers over de behoefte aan Ad-opleidingen. Het georganiseerde bedrijfsleven en/of individuele werkgevers dienen bij voorkeur zich te committeren aan de inzet van Adafgestudeerden bij hun organisaties. Hieronder worden verschillende positieve en negatieve punten van de Ad-opleidingen vanuit het werkgeversperspectief besproken, waarbij wel rekening moet worden gehouden met het zogeheten 'free rider' gedrag van werkgevers, waardoor vrijblijvende toezeggingen zonder (baan)garanties tot overschatting van de arbeidsmarktrelevantie van Ad-opleidingen kunnen leiden.

De bekendheid van de associate degree onder werkgevers is beperkt. Ongeveer $40 \%$ van de werkgevers heeft nog nooit van een Ad gehoord, tegenover $50 \%$ die er wel ooit van gehoord heeft, maar niet precies weet wat een Ad inhoudt of er geen ervaring mee heeft. Slechts $10 \%$ van de werkgevers geeft aan persoonlijke ervaring met de Ad te hebben. De aantrekkelijkheid van een Ad voor de werkgever is ook nog niet bijster positief. Slechts één op de vijf werkgevers ziet een absolute toegevoegde waarde in de Ad-opleidingen.

Werkgevers zijn vaak van mening dat het medewerkers op mbo niveau 4 schort aan analytisch vermogen, en veel werkgevers zien de oplossing in additionele scholing. De helft van de werkgevers geeft echter aan dat een volledige bacheloropleiding in combinatie met werk te belastend is, en moeilijk te combineren met een werk- en privésituatie van de werknemer. Hierin zou een Ad-opleiding dus een goede oplossing kunnen zijn. Ten opzichte van de bacheloropleiding is een Ad-programma volgens werkgevers vooral aantrekkelijk vanwege het praktijkgerichte karakter van het programma en de kortere duur. Dat de Ad leidt tot een wettelijk erkende kwalificatie is de grootste meerwaarde van de Ad ten opzichte van een in-house- of brancheopleiding. Werkgevers zijn over het algemeen ook tevreden met de Ad-opleidingen: Meer dan de helft van de werkgevers met persoonlijke ervaring met de Ad zou de Ad ook aanraden aan andere werkgevers.

Werkgevers hebben vaak moeite te concretiseren of en hoe de functie-inhoud van Ad'ers in hun organisatie zich de komende jaren zal ontwikkelen. Wel geven werkgevers aan dat er steeds meer van werknemers gevraagd wordt. Functies op mbo-niveau worden complexer, mbo-diploma's worden minder waard, en de behoefte aan hoger opgeleiden wordt groter. Ook geven werkgevers aan dat gedragsmatige competenties belangrijker steeds worden.

De belangrijkste reden voor het gebruik maken van het scholingsaanbod van Ad-opleidingen door werkgevers kwam doordat men deze toevallig tegen kwam, of actief benaderd werd door mbo- of hbo-instellingen. Een kwart van de werkgevers met persoonlijke ervaring met een Ad-opleiding heeft er voor het eerst via hbo-instellingen van gehoord. Hier ligt dus een aandachtspunt voor de aanbieders van Ad-opleidingen: Het aftasten van het werkveld om Ad-opleidingen meer bekendheid en een positieve naam mee te geven. 


\section{Conclusie}

In deze factsheet zijn verschillende aandachtspunten uiteengezet voor een haalbaarheidsstudie voor de businesscase van de twee RAC's. De bovenstaande resultaten worden hier kort per domein samengevat.

\section{Logistiek}

De onderbouwing voor de behoefte aan een associate degree opleiding in dit domein laat een wisselend beeld zien. De overbenutting van mbo niveau 4 gediplomeerden is gemiddeld, en het lage percentage dat aanvullende training volgt lijkt minder aanleiding om een associate degree aan te bieden. Het lage aandeel dat doorstroomt naar het hbo is echter wel een indicatie voor de behoefte aan een aanvullende Ad-opleiding. In termen van upgrading is er een gemengd beeld te zien tussen enerzijds beroepen die een constant opleidingsniveau behouden, en anderzijds beroepen die een steeds hoger aandeel hbo'ers ten opzichte van mbo'ers hebben. Hieruit blijkt dat bij sommige beroepen wel vraag kan zijn naar Ad'ers, en bij andere beroepen minder. Er is sprake van een hoge werkloosheid onder verwante opleidingen, en deze is ook hoger dan het gemiddelde van de vergelijkbare sector. De verticale aansluiting is laag voor het mbo en gemiddeld voor het hbo. Hierdoor is het mogelijk dat Ad'ers uit deze domeinen met een niet al te beste arbeidsmarktsituatie geconfronteerd zullen worden. Toegespitst op de twee regio's van de RAC's, zijn er slechtere arbeidsmarktperspectieven in deze regio's dan landelijk (met uitzondering voor mbo 4 verwante opleidingen in regio Den Bosch). De verwachte arbeidsmarktperspectieven voor de middellange termijn (tot 2020) zijn slecht.

De onderbouwing van een arbeidsmarktbehoefte aan een Ad-opleiding in de Logistiek is moeizaam. De lage doorstroom naar het hbo en een wisselend beeld van upgrading zijn de enige twee positieve factoren die pleiten voor het starten van een Ad-opleiding in dit domein.

\section{Agro foods}

Uit de analyse van de behoefte aan een associate degree opleiding komt naar voren dat er een lage overbenutting van mbo niveau 4 gediplomeerden is, en dat slechts een laag percentage aanvullende training volgt. Dit geeft minder aanleiding om een associate degree aan te bieden, hoewel het lage aandeel dat doorstroomt naar het hbo een indicatie kan vormen voor de behoefte aan een aanvullende Ad-opleiding. Wel is een sterke upgrading zichtbaar: er bevinden zich steeds meer hbo gediplomeerden ten opzichte van mbo gediplomeerden in de verwante beroepen. De werkloosheid voor de verwante opleidingen is vrij hoog (en ook hoger dan het sectorgemiddelde) en de aansluiting gemiddeld. Hierdoor zijn de kansen op werk naar verwachting slechter voor Adgediplomeerden uit dit domein, maar is de kans op werk op niveau gemiddeld. Beide arbeidsmarktregio's doen het goed op de arbeidsmarkt, waardoor gediplomeerden van een Adopleiding hier succesvol zouden kunnen zijn. De arbeidsmarktperspectieven op de middellange termijn zijn goed voor Agro foods.

Er zijn sterke aanwijzingen dat er een behoefte is aan een associate degree in dit domein. $\mathrm{Er}$ stroomt een laag aandeel door naar het hbo terwijl er sterke upgrading plaatsvindt in de verwante beroepen. Ook doen verwante beroepen het goed in de beide arbeidsmarktregio's waar de RAC's worden opgericht. 
ICT

Deze sector heeft de hoogste overbenutting van mbo niveau 4 gediplomeerden, en een combinatie van een gemiddeld aandeel dat aanvullende training nodig heeft met een lage doorstroom naar het hbo. Dit is een sterke indicatie is van een arbeidsmarktbehoefte aan associate degrees in dit domein. Daarnaast is er sprake van een sterke upgrading in de verwante beroepen. Wel is de werkloosheid hoog bij de verwante opleidingen (en hoger dan het sectorgemiddelde) bij het mbo maar laag (en lager dan het sectorgemiddelde) bij het hbo. Ook de verticale aansluiting is beter bij het hbo dan het mbo. De regio's doen het ook overwegend beter dan landelijk qua werkloosheidspercentages. De arbeidsmarktperspectieven op de middellange termijn zijn beter voor het hbo dan het mbo.

Concluderend kan gesteld worden dat er wel degelijk behoefte is aan een Ad-opleiding in de ICT. Een aanrader is wel om de focus meer te leggen op competenties die nodig zijn in hbo beroepen dan in mbo beroepen, gezien de lagere werkloosheidspercentages (zowel in zijn geheel als per regio) en de betere arbeidsmarktperspectieven van de hbo-gediplomeerden dan de mbogediplomeerden.

\section{Techniek}

Bij het domein techniek is er sprake van een gemiddelde overbenutting van mbo niveau 4. Wel is er een gemiddeld aandeel dat aanvullende training nodig heeft, in combinatie met een lage doorstroom naar het hbo. Dit is een indicatie is van een arbeidsmarktbehoefte naar Ad'ers. Ook is er sterk sprake van upgrading in de verwante beroepen. De werkloosheid voor de verwante opleidingen is laag, en ook lager dan het sectorgemiddelde. De verticale aansluiting is gemiddeld. Hierdoor zouden Ad-gediplomeerden uit dit domein zonder veel moeite een baan op niveau moeten kunnen vinden. Ook doen beide arbeidsmarktregio's het goed op de arbeidsmarkt, waardoor gediplomeerden van een RAC hier succesvol zouden kunnen zijn. Wel zijn de arbeidsmarktperspectieven op de middellange termijn slechter voor het mbo dan voor het hbo.

Bij het domein techniek is er een sterke indicatie van een arbeidsmarktbehoefte aan een Adopleiding. Ook hier zou de focus meer op hbo beroepen gelegd moeten worden dan op mbo beroepen, aangezien daarvoor de middellangetermijnperspectieven gunstiger zijn.

\section{Zorg}

Bij het domein zorg is er sprake van de laagste overbenutting van mbo niveau 4 gediplomeerden. Wel is de combinatie van een gemiddeld aandeel dat aanvullende training nodig heeft in combinatie met aan lage doorstroom naar het hbo een indicatie van een arbeidsmarktbehoefte. De verwante beroepen laten een gemengd beeld van constante opleidingsvereisten en downgrading zien, dat wil zeggen ofwel het niveau blijft gelijk of verschuift naar steeds meer mbo'ers. Dit kan een indicatie zijn van een mindere behoefte aan een associate degree in dit domein. De werkloosheidcijfers zijn hoger bij het mbo dan het hbo, en ook de verticale aansluiting is slechter bij mbo'ers. De arbeidsmarktsituatie is gunstiger in Bergen op Zoom dan in Den Bosch. De middellangetermijnperspectieven voor verwante opleidingen zijn matig.

Alles samengenomen is er aanleiding om te concluderen dat er een behoefte is aan Adopleidingen in dit domein. $\mathrm{Er}$ is sprake van een combinatie van downgrading (steeds meer mbo'ers) binnen de verwante beroepen, maar toch slechtere werkloosheidscijfers voor mbo'ers 
dan hbo'ers. Een oplossing zou kunnen zijn om de opleiding eerst alleen in Bergen op Zoom te starten, waar de arbeidsmarktsituatie in dit domein wat gunstiger is.

\section{Economie}

Een gemiddelde overbenutting van mbo-schoolverlaters en een laag percentage dat aanvullende training volgt geeft minder aanleiding om een associate degree aan te bieden, hoewel het lage aandeel dat doorstroomt naar het hbo een indicatie kan vormen voor een vervolgopleiding in de vorm van een Ad. Ook laat dit domein een gemengd beeld zien tussen enerzijds beroepen die een constant opleidingsniveau behouden en anderzijds beroepen waar sprake is van upgrading. Hieruit blijkt dat bij sommige beroepen wel vraag kan zijn naar Ad'ers, en bij andere beroepen minder. Ook is er sprake van een hoge werkloosheid onder verwante opleidingen, en deze is ook hoger dan het gemiddelde van de vergelijkbare sector. De verticale aansluiting is laag voor het mbo en gemiddeld voor het hbo. Hierdoor is de verwachting dat Ad'ers uit deze domeinen met een niet al te beste arbeidsmarktsituatie geconfronteerd zullen worden. De betreffende arbeidsmarktregio's bij de RAC's hebben gunstigere werkloosheidspercentages in regio Den Bosch dan in regio Bergen op Zoom. De arbeidsmarktperspectieven voor de middellange termijn zijn beter voor het mbo dan voor het hbo.

Al met al laat dit domein een overwegend wisselend beeld zien. Door het wisselende beeld van upgrading is er in sommige beroepen bij dit domein wel ruimte voor Ad-gediplomeerden en in andere beroepen minder. Een eventuele oplossing zou liggen in het meer verschuiven van de inhoud van de Ad-opleiding in de richting van de verwante mbo opleidingen, en focussen op het vinden van werk binnen de RAC-regio's. Daarnaast zou het plaatsen van een RAC in alleen regio Den Bosch betere (regionale) arbeidsmarktperspectieven kunnen bieden.

\section{Toekomst van de RAC's}

Voor de meeste opleidingen is er een onderbouwing te vinden voor het opnemen van deze opleiding in de nieuwe RAC's. Ook is er bij bedrijven en instellingen wel degelijk ruimte voor een Ad-opleiding, maar moeten werkgevers hier wel op gewezen worden. Hier ligt dus een aandachtspunt voor de aanbieders van Ad-opleidingen: Het aftasten van het werkveld om Adopleidingen meer bekendheid en een positieve naam mee te geven. 


\section{Bijlagen}

Tabel 1 De AD opleidingen met hun verwante $M B O$ niveau 4 (BOL) en hbo bachelor opleidingen.

\begin{tabular}{|c|c|c|c|c|}
\hline & \multicolumn{2}{|c|}{ Verwante MBO-BOL-4 opleiding } & \multicolumn{2}{|c|}{ Verwante HBO bachelor opleiding } \\
\hline & CREBO code & NAAM & CROHO code & NAAM \\
\hline \multicolumn{5}{|l|}{ Logistiek } \\
\hline \multirow[t]{4}{*}{ AD Logistiek management } & 95260 & Manager havenlogistiek & 34384 & maritiem officier \\
\hline & 91870 & $\begin{array}{l}\text { Manager transport en } \\
\text { logistiek }\end{array}$ & 34390 & $\begin{array}{l}\text { logistiek en technische } \\
\text { vervoerskunde }\end{array}$ \\
\hline & 90413 & Mediavormgever & 34074 & Watermanagement \\
\hline & & & 34092 & $\begin{array}{l}\text { Communication and } \\
\text { Multimedia Design }\end{array}$ \\
\hline \multicolumn{5}{|l|}{ Agro Foods } \\
\hline \multirow[t]{6}{*}{ Geen AD beschikbaar } & 95728 & $\begin{array}{l}\text { Maritiem officier alle } \\
\text { schepen }\end{array}$ & 34332 & Aquatische ecotechnologie \\
\hline & 95729 & $\begin{array}{l}\text { Scheepswerktuigkundige } \\
\text { alle schepen }\end{array}$ & 34369 & Energie en procestechnologie \\
\hline & 93715 & Microbiologisch analist & 34275 & Chemische technologie \\
\hline & 97371 & $\begin{array}{l}\text { Toezichthouder milieu en } \\
\text { ruimte }\end{array}$ & 34284 & Milieukunde \\
\hline & 97372 & Milieufunctionaris & 34396 & Chemie \\
\hline & 95730 & Stuurman alle schepen & 34397 & $\begin{array}{l}\text { Biologie en Medisch } \\
\text { laboratoriumonderwijs }\end{array}$ \\
\hline \multicolumn{5}{|l|}{ ICT } \\
\hline \multirow{3}{*}{$\begin{array}{l}\text { AD Cross mediale } \\
\text { communicatie }\end{array}$} & 95321 & ICT-beheerder & 39118 & Business IT \& Management \\
\hline & 90414 & Mediavormgever & 34475 & Technische Informatica \\
\hline & 95313 & Mediadeveloper & 34479 & Informatica/Informatica \\
\hline \multirow{2}{*}{$\begin{array}{l}\text { AD Business IT\& } \\
\text { Management }\end{array}$} & 90411 & Mediavormgever & 34404 & bedrijfskundige Informatica \\
\hline & 93191 & ICT-beheer (ICT-beheerder) & 34261 & $\begin{array}{l}\text { Bouwtechnische } \\
\text { bedrijfskunde }\end{array}$ \\
\hline AD ICT-Beheer & 95323 & Netwerkbeheerder & 34421 & Technische Bedrijfskunde \\
\hline \multicolumn{5}{|l|}{ AD Servicemanagement } \\
\hline \multicolumn{5}{|l|}{ Zorg } \\
\hline \multirow{10}{*}{$\begin{array}{l}\text { AD Management in de } \\
\text { Zorg (HR) } \\
\text { AD Pedagogisch educatief } \\
\text { medewerker (HR) }\end{array}$} & 94910 & $\begin{array}{l}\text { Medewerker sociale } \\
\text { zekerheid }\end{array}$ & 39219 & $\begin{array}{l}\text { Gezondheidszorg } \\
\text { Technologie }\end{array}$ \\
\hline & 91370 & Sociaal-cultureel werker & 34538 & Management in de Zorg \\
\hline & 90350 & Praktijkopleider & 34560 & $\begin{array}{l}\text { Opleiding tot } \\
\text { Verpleegkundige }\end{array}$ \\
\hline & 93510 & MBO-Verpleegkundige & 34616 & $\begin{array}{l}\text { Maatsc. Werk en } \\
\text { Dienstverlening }\end{array}$ \\
\hline & 95520 & Mbo-Verpleegkundige & 34617 & Soc. Ped. Hulpverlening \\
\hline & 91310 & Doktersassistent & 35158 & Pedagogiek \\
\hline & 92632 & $\begin{array}{l}\text { Gespecialiseerd } \\
\text { pedagogisch medewerker } 4 \\
\text { kinderopvang }\end{array}$ & 34610 & $\begin{array}{l}\text { Cult. En maatschappelijke } \\
\text { Vorming }\end{array}$ \\
\hline & 92631 & $\begin{array}{l}\text { Pedagogisch medewerker } 4 \\
\text { jeugdzorg }\end{array}$ & 34116 & Social Work \\
\hline & 92661 & $\begin{array}{l}\text { Persoonlijk begeleider } \\
\text { gehandicaptenzorg }\end{array}$ & & \\
\hline & 92662 & $\begin{array}{l}\text { Persoonlijk begeleider } \\
\text { specifieke doelgroepen }\end{array}$ & & \\
\hline Techniek & & & & \\
\hline
\end{tabular}




\begin{tabular}{|c|c|c|c|c|}
\hline \multirow{3}{*}{$\begin{array}{l}\text { AD Technische } \\
\text { Bedrijfskunde }\end{array}$} & 90240 & Operator C & & \\
\hline & 94412 & $\begin{array}{l}\text { Vliegtuigonderhoud } \\
\text { (Technische mechanica) }\end{array}$ & 30026 & Mechatronica \\
\hline & 97371 & $\begin{array}{l}\text { Toezichthouder milieu en } \\
\text { ruimte }\end{array}$ & 34267 & Elekotrotechniek \\
\hline \multirow{4}{*}{$\begin{array}{l}\text { AD Maintenance } \\
\text { Mechanics }\end{array}$} & 94421 & Technicus & 39118 & Business IT \& Management \\
\hline & 93430 & $\begin{array}{l}\text { Technisch Specialist } \\
\text { Personenauto's }\end{array}$ & 34421 & Technische Bedrijfskunde \\
\hline & 93714 & Chemisch-fysisch analist & 39201 & Integrale Veiligheid \\
\hline & 94262 & Mechatronicus & 34280 & Werktuigbouwkunde \\
\hline \multirow[t]{8}{*}{ AD Engineering } & 93873 & $\begin{array}{l}\text { kaderfunctionaris } \\
\text { uitvoering bouw en infra }\end{array}$ & 34263 & Bouwkunde \\
\hline & 94261 & Allround machinebouwer & 34279 & Civiele Techniek \\
\hline & 93711 & Analist klinische chemie & 34396 & Chemie \\
\hline & 93712 & Analist pathologie & & \\
\hline & 93715 & Microbiologisch analist & & \\
\hline & 94052 & $\begin{array}{l}\text { Middenkaderfunctionaris } \\
\text { Infra }\end{array}$ & & \\
\hline & 94051 & $\begin{array}{l}\text { Middenkaderfunctionaris } \\
\text { Bouw }\end{array}$ & & \\
\hline & 97372 & Milieufunctionaris & & \\
\hline \multicolumn{5}{|l|}{ Economie } \\
\hline \multirow[t]{12}{*}{ AD Officemanagement } & 93212 & Bedrijfsadministrateur & 30016 & Avanced Business Creation \\
\hline & 93211 & Assistent-accountant & 34401 & Bedrijfseconomie \\
\hline & 94892 & $\begin{array}{l}\text { Juridisch medewerker } \\
\text { openbaar bestuur }\end{array}$ & 34402 & Commerciële Economie \\
\hline & 93494 & $\begin{array}{l}\text { Vestigingsmanager } \\
\text { groothandel }\end{array}$ & 34405 & Communicatie \\
\hline & 90500 & $\begin{array}{l}\text { Commercieel medewerker } \\
\text { bank-en } \\
\text { verzekeringswezen }\end{array}$ & 34407 & $\mathrm{IBL}$ \\
\hline & 90532 & Marketing medewerker & 34139 & Bedrijfskunde MER \\
\hline & 95391 & $\begin{array}{l}\text { Directiesecretaresse/ } \\
\text { Managementassistent }\end{array}$ & 34435 & $\begin{array}{l}\text { Opleiding voor Management, } \\
\text { Economie }\end{array}$ \\
\hline & 94891 & $\begin{array}{l}\text { Juridisch medewerker } \\
\text { zakelijke dienstverlening }\end{array}$ & 34936 & Int. Business Management \\
\hline & 90531 & $\begin{array}{l}\text { Assistent } \\
\text { communicatiemedewerker }\end{array}$ & 30110 & $\begin{array}{l}\text { Vitaliteitsmanagement en } \\
\text { Toerisme }\end{array}$ \\
\hline & & & 34422 & SBRM \\
\hline & & & 34464 & $\begin{array}{l}\text { Bestuurskunde/Overheidsma } \\
\text { nagement }\end{array}$ \\
\hline & & & 34406 & Accountancy \\
\hline
\end{tabular}


Tabel 2 Upgrading per verwant beroep

\begin{tabular}{|c|c|c|c|c|c|c|}
\hline Niveau & Naam Beroep & & 2005-2009 & $2010-2014$ & Verandering & Typering \\
\hline \multirow[t]{3}{*}{ mbo } & $\begin{array}{l}\text { Leidsters kinderopvang en } \\
\text { onderwijsassistenten }\end{array}$ & mbo 4 & 53,6 & 53,5 & & \\
\hline & & hbo & 67,1 & 69 & & \\
\hline & & $\mathrm{Hbo} / \mathrm{mbo}$ & 125,2 & 129,0 & 4 & Constant \\
\hline \multirow[t]{3}{*}{ mbo } & $\begin{array}{l}\text { Verkoopmedewerkers } \\
\text { detailhandel }\end{array}$ & $\mathrm{mbo} 4$ & 34,7 & 33,4 & & \\
\hline & & hbo & 42,6 & 42,3 & & \\
\hline & & $\mathrm{Hbo} / \mathrm{mbo}$ & 122,8 & 126,6 & 4 & Constant \\
\hline \multirow[t]{3}{*}{$\mathrm{mbo}$} & Administratief medewerkers & mbo 4 & 40,2 & 39,2 & & \\
\hline & & hbo & 52,2 & 53,4 & & \\
\hline & & $\mathrm{Hbo} / \mathrm{mbo}$ & 129,9 & 136,2 & 6 & Upgrading \\
\hline \multirow[t]{3}{*}{ mbo } & Receptionisten en telefonisten & mbo 4 & 37,5 & 38,8 & & \\
\hline & & hbo & 47,8 & 54,7 & & \\
\hline & & $\mathrm{Hbo} / \mathrm{mbo}$ & 127,5 & 141,0 & 14 & $\begin{array}{l}\text { Sterke } \\
\text { upgrading }\end{array}$ \\
\hline \multirow[t]{3}{*}{$\mathrm{mbo}$} & Boekhoudkundig medewerkers & $\mathrm{mbo} 4$ & 41,6 & 45,4 & & \\
\hline & & hbo & 60,2 & 64,5 & & \\
\hline & & $\mathrm{Hbo} / \mathrm{mbo}$ & 144,7 & 142,1 & -3 & Constant \\
\hline \multirow[t]{3}{*}{ mbo } & $\begin{array}{l}\text { Transportplanners en logistiek } \\
\text { medewerkers }\end{array}$ & mbo 4 & 40,1 & 42,4 & & \\
\hline & & hbo & 56,5 & 59,9 & & \\
\hline & & $\mathrm{Hbo} / \mathrm{mbo}$ & 140,9 & 141,3 & 0 & Constant \\
\hline \multirow[t]{3}{*}{$\mathrm{mbo}$} & $\begin{array}{l}\text { Managers detail- en } \\
\text { groothandel }\end{array}$ & $\mathrm{mbo} 4$ & 43,4 & 41,7 & & \\
\hline & & hbo & 61,3 & 59,8 & & \\
\hline & & $\mathrm{Hbo} / \mathrm{mbo}$ & 141,2 & 143,4 & 2 & Constant \\
\hline \multirow[t]{3}{*}{ mbo } & Verpleegkundigen & mbo 4 & 70,3 & 68,6 & & \\
\hline & & hbo & 75,6 & 75,2 & & \\
\hline & & $\mathrm{Hbo} / \mathrm{mbo}$ & 107,5 & 109,6 & 2 & Constant \\
\hline \multirow[t]{3}{*}{$\mathrm{mbo}$} & $\begin{array}{l}\text { Sociaal werkers, groeps- en } \\
\text { woonbegeleiders }\end{array}$ & mbo 4 & 48,7 & 46,8 & & \\
\hline & & hbo & 78,5 & 77,3 & & \\
\hline & & $\mathrm{Hbo} / \mathrm{mbo}$ & 161,2 & 165,2 & 4 & Constant \\
\hline $\mathrm{mbo}$ & Verzorgenden & mbo 4 & 60,7 & 61,2 & & \\
\hline
\end{tabular}




\begin{tabular}{|c|c|c|c|c|c|c|}
\hline & & hbo & 64,8 & 66,5 & & \\
\hline & & $\mathrm{Hbo} / \mathrm{mbo}$ & 106,8 & 108,7 & 2 & Constant \\
\hline \multirow[t]{3}{*}{ hbo } & $\begin{array}{l}\text { Grafisch vormgevers en } \\
\text { productontwerpers }\end{array}$ & mbo 4 & 29,7 & 28,5 & & \\
\hline & & hbo & 52,2 & 60,7 & & \\
\hline & & $\mathrm{Hbo} / \mathrm{mbo}$ & 175,8 & 213,0 & 37 & $\begin{array}{l}\text { Sterke } \\
\text { upgrading }\end{array}$ \\
\hline \multirow[t]{3}{*}{ hbo } & $\begin{array}{l}\text { Adviseurs marketing, public } \\
\text { relations en sales }\end{array}$ & mbo 4 & 17,4 & 17 & & \\
\hline & & hbo & 56,4 & 59,3 & & \\
\hline & & $\mathrm{Hbo} / \mathrm{mbo}$ & 324,1 & 348,8 & 25 & $\begin{array}{l}\text { Sterke } \\
\text { upgrading }\end{array}$ \\
\hline \multirow[t]{3}{*}{ hbo } & $\begin{array}{l}\text { Vertegenwoordigers en } \\
\text { inkopers }\end{array}$ & $\mathrm{mbo} 4$ & 42,8 & 37,7 & & \\
\hline & & hbo & 67,6 & 67,3 & & \\
\hline & & $\mathrm{Hbo} / \mathrm{mbo}$ & 157,9 & 178,5 & 21 & $\begin{array}{l}\text { Sterke } \\
\text { upgrading }\end{array}$ \\
\hline \multirow[t]{3}{*}{ hbo } & $\begin{array}{l}\text { Financieel specialisten en } \\
\text { economen }\end{array}$ & mbo 4 & 6,6 & 10,5 & & \\
\hline & & hbo & 56,9 & 56,5 & & \\
\hline & & $\mathrm{Hbo} / \mathrm{mbo}$ & 862,1 & 538,1 & -324 & $\begin{array}{l}\text { Sterke } \\
\text { downgrading }\end{array}$ \\
\hline \multirow[t]{3}{*}{ hbo } & $\begin{array}{l}\text { Bedrijfskundigen en } \\
\text { organisatieadviseurs }\end{array}$ & mbo 4 & 9,8 & 11,2 & & \\
\hline & & hbo & 45,5 & 45,3 & & \\
\hline & & $\mathrm{Hbo} / \mathrm{mbo}$ & 464,3 & 404,5 & -60 & $\begin{array}{l}\text { Sterke } \\
\text { downgrading }\end{array}$ \\
\hline \multirow[t]{3}{*}{ hbo } & Boekhouders & mbo 4 & 42,7 & 39,3 & & \\
\hline & & hbo & 66,7 & 66,2 & & \\
\hline & & $\mathrm{Hbo} / \mathrm{mbo}$ & 156,2 & 168,4 & 12 & $\begin{array}{l}\text { Sterke } \\
\text { upgrading }\end{array}$ \\
\hline \multirow[t]{3}{*}{ hbo } & Zakelijke dienstverleners & mbo 4 & 24,8 & 23 & & \\
\hline & & hbo & 63,1 & 63,7 & & \\
\hline & & $\mathrm{Hbo} / \mathrm{mbo}$ & 254,4 & 277,0 & 23 & $\begin{array}{l}\text { Sterke } \\
\text { upgrading }\end{array}$ \\
\hline \multirow[t]{3}{*}{ hbo } & Managers zorginstellingen & mbo 4 & 22,6 & 20,3 & & \\
\hline & & hbo & 67,7 & 64,6 & & \\
\hline & & $\mathrm{Hbo} / \mathrm{mbo}$ & 299,6 & 318,2 & 19 & $\begin{array}{l}\text { Sterke } \\
\text { upgrading }\end{array}$ \\
\hline \multirow[t]{3}{*}{ hbo } & $\begin{array}{l}\text { Ingenieurs (geen } \\
\text { elektrotechniek) }\end{array}$ & $\mathrm{mbo} 4$ & 17,4 & 15,5 & & \\
\hline & & hbo & 63 & 60,3 & & \\
\hline & & $\mathrm{Hbo} / \mathrm{mbo}$ & 362,1 & 389,0 & 27 & $\begin{array}{l}\text { Sterke } \\
\text { upgrading }\end{array}$ \\
\hline hbo & Technici bouwkunde en natuur & mbo 4 & 55,2 & 51,5 & & \\
\hline
\end{tabular}




\begin{tabular}{|c|c|c|c|c|c|c|}
\hline & & hbo & 79,8 & 76,8 & & \\
\hline & & $\mathrm{Hbo} / \mathrm{mbo}$ & 144,6 & 149,1 & 5 & Upgrading \\
\hline \multirow[t]{3}{*}{ hbo } & $\begin{array}{l}\text { Software-en } \\
\text { applicatieontwikkelaars }\end{array}$ & $\mathrm{mbo} 4$ & 10,9 & 12,5 & & \\
\hline & & hbo & 56 & 57,1 & & \\
\hline & & $\mathrm{Hbo} / \mathrm{mbo}$ & 513,8 & 456,8 & -57 & $\begin{array}{l}\text { Sterke } \\
\text { downgrading }\end{array}$ \\
\hline \multirow[t]{3}{*}{ hbo } & $\begin{array}{l}\text { Databank- en } \\
\text { netwerkspecialisten }\end{array}$ & mbo 4 & 38,1 & 36,6 & & \\
\hline & & hbo & 65 & 66,1 & & \\
\hline & & $\mathrm{Hbo} / \mathrm{mbo}$ & 170,6 & 180,6 & 10 & $\begin{array}{l}\text { Sterke } \\
\text { upgrading }\end{array}$ \\
\hline \multirow[t]{3}{*}{ hbo } & $\begin{array}{l}\text { Gespecialiseerd } \\
\text { verpleegkundigen }\end{array}$ & $\mathrm{mbo} 4$ & 7,3 & 17,5 & & \\
\hline & & hbo & 90,7 & 85,4 & & \\
\hline & & $\mathrm{Hbo} / \mathrm{mbo}$ & 1242,5 & 488,0 & -754 & $\begin{array}{l}\text { Sterke } \\
\text { downgrading }\end{array}$ \\
\hline \multirow[t]{3}{*}{ hbo } & Maatschappelijk werkers & mbo 4 & 9,3 & 14,9 & & \\
\hline & & hbo & 57 & 67,8 & & \\
\hline & & $\mathrm{Hbo} / \mathrm{mbo}$ & 612,9 & 455,0 & -158 & $\begin{array}{l}\text { Sterke } \\
\text { downgrading }\end{array}$ \\
\hline \multirow[t]{3}{*}{ hbo } & Laboranten & $\mathrm{mbo} 4$ & 24,7 & 26,8 & & \\
\hline & & hbo & 85,6 & 82,4 & & \\
\hline & & $\mathrm{Hbo} / \mathrm{mbo}$ & 346,5587 & 307,4627 & 39,1 & $\begin{array}{l}\text { Sterke } \\
\text { upgrading }\end{array}$ \\
\hline & & & & & & \\
\hline
\end{tabular}


Tabel 3 Vergelijking domein en sector

\begin{tabular}{|c|c|c|c|c|c|}
\hline Sector & $\begin{array}{l}\text { Vergelijkbare } \\
\text { domeinen }\end{array}$ & $\%$ werkloos sector & $\begin{array}{l}\text { Vergelijking domein en } \\
\text { sector }\end{array}$ & $\begin{array}{l}\text { \%werkzaam } \\
\text { minimaal eigen } \\
\text { niveau }\end{array}$ & $\begin{array}{l}\text { Vergelijking } \\
\text { domein en sector }\end{array}$ \\
\hline \multirow[t]{3}{*}{ Logistiek } & Logistiek & \multirow[t]{3}{*}{$\begin{array}{l}4 \%(\mathrm{mbo}) \\
5 \%(\mathrm{hbo})\end{array}$} & $\begin{array}{l}\text { Hoger (mbo), hoger } \\
\text { (hbo) }\end{array}$ & \multirow[t]{3}{*}{$\begin{array}{l}77 \%(\mathrm{mbo}), 84 \% \\
\text { (hbo) }\end{array}$} & $\begin{array}{l}\text { Lager (mbo), } \\
\text { lager (hbo) }\end{array}$ \\
\hline & ICT & & $\begin{array}{l}\text { Hoger (mbo), lager } \\
\text { (hbo) }\end{array}$ & & $\begin{array}{l}\text { Hoger (mbo), } \\
\text { hoger (hbo) }\end{array}$ \\
\hline & Techniek & & Lager (mbo), lager (hbo) & & $\begin{array}{l}\text { Hoger (mbo), } \\
\text { lager (hbo) }\end{array}$ \\
\hline Landbouw & Agro foods & $\begin{array}{l}8 \%(\mathrm{mbo}) \\
8 \% \text { (hbo) }\end{array}$ & $\begin{array}{l}\text { Hoger (mbo), lager } \\
\text { (hbo) }\end{array}$ & $\begin{array}{l}68 \% \text { (mbo), } 73 \% \\
\text { (hbo) }\end{array}$ & $\begin{array}{l}\text { Hoger (mbo), } \\
\text { lager (hbo) }\end{array}$ \\
\hline $\begin{array}{l}\text { Gezondheids- } \\
\text { zorg }\end{array}$ & Zorg & $\begin{array}{l}3 \% \text { (mbo), } \\
3 \% \text { (hbo) }\end{array}$ & $\begin{array}{l}\text { Hoger (mbo), hoger } \\
\text { (mbo) }\end{array}$ & $\begin{array}{l}88 \% \text { (mbo), } 78 \% \\
\text { (hbo) }\end{array}$ & $\begin{array}{l}\text { Gelijk (mbo), } \\
\text { lager ( } \mathrm{hbo} \text { ) }\end{array}$ \\
\hline Economie & Economie & $\begin{array}{l}10 \%(\mathrm{mbo}) \\
8 \%(\mathrm{hbo})\end{array}$ & $\begin{array}{l}\text { Hoger (mbo), gelijk } \\
\text { (hbo) }\end{array}$ & $\begin{array}{l}71 \% \text { (mbo), } \\
76 \% \text { (hbo) }\end{array}$ & $\begin{array}{l}\text { Lager (mbo), } \\
\text { Lager (hbo) }\end{array}$ \\
\hline
\end{tabular}

Tabel 4 Arbeidsmarktperspectieven tot 2020

\begin{tabular}{|c|c|c|c|c|}
\hline & Verwante mbo domeinen & ITA & $\begin{array}{l}\text { Verwante hbo } \\
\text { domeinen }\end{array}$ & ITA \\
\hline \multirow[t]{2}{*}{$\begin{array}{l}\text { Logistiek } \\
\text { AD Logistiek management }\end{array}$} & mbo 4 transport en logistiek & slecht & $\begin{array}{l}\text { hbo transport en } \\
\text { logistiek }\end{array}$ & goed \\
\hline & mbo 4 media en vormgeving & slecht & hbo communicatie & slecht \\
\hline \multirow[t]{2}{*}{ Agro foods } & $\begin{array}{l}\text { mbo } 4 \text { voedsel, natuur en } \\
\text { milieu }\end{array}$ & goed & Hbo chemie & zeer goed \\
\hline & & & Hbo natuur en milieu & redelijk \\
\hline \multirow{2}{*}{$\begin{array}{l}\text { ICT } \\
\text { AD Cross mediale communicatie, ADBusiness IT\& } \\
\text { Management, } A D \text { ICT-Beheer, } A D \\
\text { Servicemanagement }\end{array}$} & mbo 4 media en vormgeving & slecht & hbo bedrijfseconomie & matig \\
\hline & mbo 4 informatica & slecht & hbo informatica & goed \\
\hline \multirow{3}{*}{$\begin{array}{l}\text { Zorg } \\
\text { AD Management in de Zorg, AD Pedagogisch } \\
\text { educatief medewerker }\end{array}$} & mbo 4 gezondheidszorg & matig & $\begin{array}{l}\text { hbo verpleegkunde en } \\
\text { medische diagnostiek }\end{array}$ & matig \\
\hline & mbo 4 maatschappelijke zorg & slecht & hbo pedagogiek & redelijk \\
\hline & & & hbo sociaal cultureel & slecht \\
\hline \multirow{4}{*}{$\begin{array}{l}\text { Techniek } \\
\text { AD Technische Bedrijfskunde, AD Maintenance } \\
\text { Mechanics, AD Engineering }\end{array}$} & mbo 4 voertuigtechniek & matig & hbo elektrotechniek & goed \\
\hline & mbo 4 transport en logistiek & slecht & $\begin{array}{l}\text { hbo bouwkunde en } \\
\text { civiele techniek }\end{array}$ & goed \\
\hline & mbo 4 technische installatie & goed & hbo chemie & zeer goed \\
\hline & $\begin{array}{l}\text { mbo } 4 \text { werktuigbouwkunde } \\
\text { en metaalbewerking }\end{array}$ & goed & & \\
\hline \multirow{3}{*}{$\begin{array}{l}\text { Economie } \\
A D \text { Officemanagement, } A D \text { Ondernemen, } \\
A D \text { Vitaliteitsmanagement en toerisme }\end{array}$} & $\begin{array}{l}\text { mbo } 4 \text { commercieel, financieel } \\
\text { en administratief }\end{array}$ & goed & hbo bedrijfseconomie & matig \\
\hline & mbo 4 secretarieel & redelijk & $\begin{array}{l}\text { hbo marketing en } \\
\text { commerciele economie }\end{array}$ & slecht \\
\hline & $\begin{array}{l}\text { mbo } 4 \text { facilitaire } \\
\text { dienstverlening }\end{array}$ & redelijk & $\begin{array}{l}\text { hbo accountancy en } \\
\text { financiën }\end{array}$ & redelijk \\
\hline
\end{tabular}


